The INL is a

U.S. Department of Energy

National Laboratory

operated by

Battelle Energy Alliance

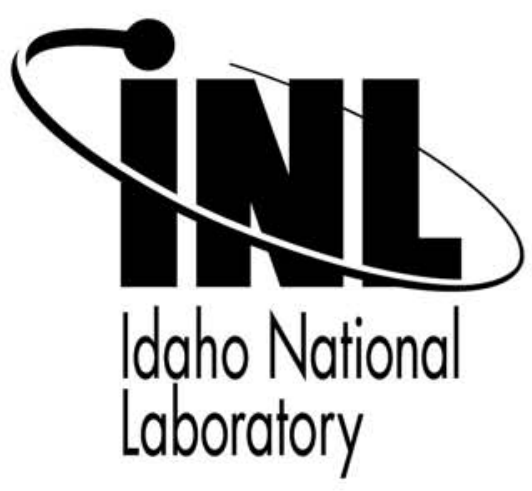

\title{
Use of a Paraffin Based Grout to Stabilize Buried Beryllium and Other Wastes
}

\section{7th International Energy Agency International Workshop on Beryllium Technology}

Gretchen E. Matthern

Neal Yancey

Darrel L. Knudson

Duane J. Hanson

\section{December 2005}

This is a preprint of a paper intended for publication in a journal or proceedings. Since changes may not be made before publication, this preprint should not be cited or reproduced without permission of the author. This document was prepared as an account of work sponsored by an agency of the United States Government. Neither the United States Government nor any agency thereof, or any of their employees, makes any warranty, expressed or implied, or assumes any legal liability or responsibility for any third party's use, or the results of such use, of any information, apparatus, product or process disclosed in this report, or represents that its use by such third party would not infringe privately owned rights. The views expressed in this paper are not necessarily those of the United States Government or the sponsoring agency. 


\title{
USE OF A PARAFFIN BASED GROUT TO STABILIZE BURIED BERYLLIUM AND OTHER WASTES
}

\author{
GRETCHEN E. MATTHERN*, NEAL A. YANCEY, DARREL L. KNUDSON, DUANE J. HANSON, \\ Idaho National Laboratory, P.O. Box 1625, Idaho Falls, Idaho, 83415 USA
}

\section{ABSTRACT}

The long term durability of WAXFIX, a paraffin based grout, was evaluated for in situ grouting of activated beryllium wastes in the Subsurface Disposal Area (SDA), a radioactive landfill at the Radioactive Waste Management Complex, part of the Idaho National Laboratory (INL). The evaluation considered radiological and biological mechanisms that could degrade the grout using data from an extensive literature search and previous tests of in situ grouting at the INL. Conservative radioactive doses for WAXFIX were calculated from the "hottest" (i.e., highest-activity) Advanced Test Reactor beryllium block in the SDA.. These results indicate that WAXFIX would not experience extensive radiation damage for many hundreds of years. Calculation of radiation induced hydrogen generation in WAXFIX indicated that grout physical performance should not be reduced beyond the effects of radiation dose on the molecular structure. Degradation of a paraffin-based grout by microorganisms in the SDA is possible and perhaps likely, but the rate of degradation will be at a slower rate than found in the literature reviewed. The calculations showed the outer $0.46 \mathrm{~m}$ (18 in.) layer of each monolith, which represents the minimum expected distance to the beryllium block, was calculated to require 1,000 to 3,600 years to be consumed. The existing data and estimations of biodegradation and radiolysis rates 
for WAXFIX/paraffin do not indicate any immediate problems with the use of WAXFIX for grouting beryllium or other wastes in the SDA..

KEYWORDS: beryllium, WAXFIX, radiation, waste, biodegradation

\section{INTRODUCTION}

The long term durability of WAXFIX, a paraffin based grout, was evaluated for in situ grouting of activated Beryllium wastes in the Subsurface Disposal Area (SDA), a radioactive landfill at the Radioactive Waste Management Complex (RWMC), part of the Idaho National Laboratory (INL). The evaluation considered radiological and biological mechanisms that could degrade the grout based on data from an extensive literature search and tests of in situ grouting at the INL. ${ }^{1}$

Between 1970 and 1993, beryllium components were buried as low-level radioactive waste after being irradiated during testing in the Advanced Test Reactor (ATR), the Materials Test Reactor, or the Engineering Test Reactor. Stabilization of the beryllium waste in the SDA is desired to reduce the release of activation products from the large chunks of beryllium metal. The primary mechanism for release of activation products is corrosion of the beryllium forms. The corrosion of beryllium is accelerated by high $\mathrm{pH}$ and moisture. WAXFIX was selected for evaluation as a grout (to be injected in situ to surround the beryllium components) due to its neutral $\mathrm{pH}$ and its ability to permeate and coat materials and prevent moisture intrusion.

WAXFIX is composed primarily of paraffins in the $\mathrm{C}_{18}-\mathrm{C}_{25}$ range with a small amount of proprietary additives, designed to enhance its handling properties as a grout. ${ }^{2}$ WAXFIX grout has a solid density between 0.8 and $0.9 \mathrm{~g} / \mathrm{cm}^{3} .3,4$ Thermal testing on WAXFIX indicates that the melting point is 
about $58^{\circ} \mathrm{C}\left(136^{\circ} \mathrm{F}\right) .{ }^{3}$ The long-term performance of WAXFIX depends on its ability to withstand the radiological, chemical, and biological conditions at the SDA.

\section{RESISTANCE TO RADIATION}

Determining the WAXFIX radiation dose is key in evaluating the potential for significant radiation damage to its crystalline structure. A worst-case estimate of the radiation dose that can be used to provide a rough order of magnitude estimate of radiation damage is presented here.

To provide a worst-case estimate of the radiation dose to the grout, an ATR beryllium block that was buried in the SDA in 1993 was selected as the radiation source; this block was the most highly irradiated of the blocks buried at that time. Estimating the current radioactive isotope inventory for this block required extending calculations made previously ${ }^{5}$ with the Oak Ridge Isotope GENeration and Depletion Code Version 2 (ORIGEN2) model. ${ }^{6}$ Calculations were extended to provide radioisotope inventories for July 1, 2004 and July 1, 2014. Results from the ORIGEN2 calculations were used as the radiation source term for calculations to estimate how much radiation enters and is absorbed by the grout.

Calculations to estimate the surface fluence rate and exposure rate for the ATR beryllium block were made using the MicroShield computer code. ${ }^{7}$ Simplifications in the modeling of the block were necessary because the ATR beryllium block has a very complicated surface and cross-sectional shape, and it has multiple holes within its geometry (Fig. 1). The block has a height of $129.54 \mathrm{~cm}(51 \mathrm{in}$.). The beryllium block was simulated in the code as a solid rectangle with an identical height, but with a length (40.15 cm [15.8 in.]) and width (26.04 cm [10.3 in.]) chosen to approximate the actual blocks cross-sectional dimensions. The density of the material for the model comprising the solid rectangle was 
adjusted to provide a total mass that was identical to the actual mass of the block. A rectangular beryllium block with $61 \mathrm{~cm}(2 \mathrm{ft})$ of paraffin wax on its outer surface was also modeled by simulating a layer of pure paraffin adjacent to the beryllium surface of the initial beryllium block model. Two feet was chosen as a likely thickness for the WAXFIX as it is jet grouted adjacent to the block. Soil and waste were not included in the model because of a lack of information on the radiation absorption characteristics of the dirt/paraffin mixture. The intent of this model was to calculate radiation fluxes near the surface of the wax that could be subtracted from the bare block fluxes to estimate how much radiation was absorbed in the wax.

Four calculations were made, a bare beryllium block and a beryllium block with wax for the year 2004 and for the year 2014. Preliminary calculations indicated there was not a substantial difference (i.e., only about $8 \%$ ) between the surface fluences on the centerline of the front (length) and sides (width) of the rectangle. As a result, radiation fluences were calculated at six positions on the front surface of each block as shown by the dots in Fig. 2 for the block with $61 \mathrm{~cm}(2 \mathrm{ft})$ of paraffin wax. Table I provides the calculated fluence rates in $\mathrm{MeV}$ per square centimeter per second and the exposure rates in gray per hour.

The energy exiting the surface of the block was calculated assuming the fluence rates were the same on the fronts and sides of the rectangle and roughly integrating the fluence rates over the area of the modeled block (the top and bottom areas were not included). The integration was performed for the surface of the bare block and the surface of the wax, and the two were subtracted to calculate the energy absorbed by the wax. Based on the integration for July 1, 2004, the rate of energy absorption in the wax was $9.30 \times 10^{19} \mathrm{MeV}$ per year. A rough check of this value was performed by assuming the hot spot (i.e., middle center) value was applicable to the entire surface, giving an absorbed energy in the wax of $12.18 \times 10^{19} \mathrm{MeV}$ per year. Integrating to include edge effects only reduced the energy absorbed by 
about $30 \%$, and may not be conservative since the integration method was simple and was only based on six points.

The fluence rate values in 2004 were compared to those calculated for 2014 . The ratio of the 2014 values to the 2004 values is 0.278 . Assuming that ${ }^{60} \mathrm{Co}$ is the only contributor to the fluence (half life 5.274 years), this ratio would be 0.269 . Comparing these ratios shows that ${ }^{60}$ Co is the primary contributor to the beryllium block fluence rate over the next 10 years.

In many materials, radiation will change the crystal lattice and deteriorate the lattice order. These changes to the crystal structure can lead to a decrease in the structural performance of the material. ${ }^{8-10} \mathrm{~A}$ limiting dose that would have a negligible effect on plastics is reported as about $10^{5}$ Gy $\left(10^{7}\right.$ Rad), and a dose that generally results in major damage is about $10^{7}$ Gy $\left(10^{9} \mathrm{Rad}\right){ }^{11}$ These results would include both damage to the crystal structure and the effect of gas phase (e.g., hydrogen and methane) in the hydrocarbon material.

A conservative estimate of the dose to WAXFIX surrounding an ATR beryllium block can be made using the highest exposure rate in Table I. Using the ${ }^{60} \mathrm{Co}$ half life, it is estimated that over the 10 -year period between 2004 and 2014, the WAXFIX would get a dose of $1.95 \times 10^{5} \mathrm{~Gy}\left(1.95 \times 10^{7} \mathrm{Rad}\right)$. This is just beginning to approach material damage for a plastic. The limiting dose for paraffin would be expected to be higher than the values quoted for plastic, based on differences in the effect of radiation on plastic crystalline structure versus paraffin structure. If all of the fluence was assumed to be from ${ }^{60} \mathrm{Co}$, the total dose possible for an infinite time would be about 2.67 X $105 \mathrm{~Gy}\left(2.67 \times 10^{7} \mathrm{Rad}\right)$. Longer lived radionuclides would continue to provide low levels of radiation for long periods of time, but the WAXFIX would not reach levels of radiation that would cause substantial damage (i.e., $10^{7}$ Gy or more) for a very long time, likely many hundreds of years or longer. 


\section{RESISTANCE TO BIODEGRADATION}

Biodegradability is important to the potential grout applications of immobilization and structural support. No data were found specifically for the biodegradability of WAXFIX, so data for paraffin, the principle ingredient of WAXFIX were used. Most microorganisms that metabolize paraffin are aerobic (some are anaerobic). ${ }^{12-14}$ Biodegradation has been demonstrated in a variety of environments including soil, aquatic systems, leaf litter, and well bores. ${ }^{12-18}$ Microorganisms that degrade hydrocarbons have been shown to account for 6 to $82 \%$ of all soil fungi and 13 to $50 \%$ of soil bacteria. ${ }^{13}$ The solid nature of wax and its low solubility in water should make it difficult for microorganisms to attack. However, the microorganisms have developed a variety of adaptations that allow them to use hydrocarbons in gas, liquid, and solid substrates. Generally, the shorter chain compounds (i.e., less than $\mathrm{C}_{10}$ ) are microbially degraded first; then the longer chain (i.e., greater than $\mathrm{C}_{10}$ ) compounds are attacked. ${ }^{19}$ Oxidizers of lower molecular weight (i.e., $\mathrm{C}_{10}$ to $\mathrm{C}_{12}$ ) paraffins generally grow more rapidly than those for higher molecular weight paraffins. ${ }^{20}$

Most of the bacteria and fungi that degrade hydrocarbons prefer a near neutral $\mathrm{pH}^{13}$; however, biodegradation has been observed in well bores with a $\mathrm{pH}$ of 4 to $9 .^{21}$ The optimum temperature is 20 to $40^{\circ} \mathrm{C}$, although degradation has been observed in temperatures ranging from -2 to $132^{\circ} \mathrm{C} \cdot{ }^{13,21,22}$ Soil water contents of 30 to $90 \%$ saturation support degradation of oil sludge. ${ }^{13}$

Many microorganisms can use hydrocarbons as a sole source of carbon. ${ }^{12}$ To degrade, sufficient quantities of hydrocarbons, oxygen, nitrogen, phosphorous, sulfur, metals, and trace compounds must also be available. ${ }^{13,20,22}$ About $150 \mathrm{mg}$ of nitrogen and $30 \mathrm{mg}$ of phosphorous are required for the conversion of $1 \mathrm{~g}$ of hydrocarbon into cell material. ${ }^{20}$ Oxygen has been identified as the rate-limiting step for biological degradation of hydrocarbons in soil. ${ }^{13}$ Surface area for cell attachment or 
emulsification of hydrocarbon is also an important determiner of the rate of hydrocarbon degradation. ${ }^{13}$ Microbial degradation is facilitated by high surface-to-volume ratios. ${ }^{12,13,22}$ For longer alkanes (greater than or equal to $\mathrm{C}_{12}$ ) with low solubilities (less than $0.01 \mathrm{mg} /$ liter), the rate of degradation is faster than the rate of dissolution. ${ }^{13}$ Generally, hydrocarbon biodegradation occurs very slowly under anaerobic conditions. $^{13,16}$

It is clear that paraffin can be biodegraded by several organisms under the proper conditions. Moisture, neutral $\mathrm{pH}$, relatively warm temperatures (i.e., 20 to $40^{\circ} \mathrm{C}$ ), the presence of oxygen, nitrogen, and phosphorous, and high surface to volume ratios favor the biodegradation of paraffin. At the SDA, some of these conditions could be met in the waste seam where the paraffin would be placed. The waste is located about $1 \mathrm{~m}$ below the surface and forms a layer 1 to $5 \mathrm{~m}$ thick. The temperature in the soil at 2 meters below the surface ranges from approximately $4-15^{\circ} \mathrm{C}$ over a year; at 6 meters below the surface, the temperature range from approximately $8-10{ }^{\circ} \mathrm{C}$ over a year. ${ }^{23}$ The water in the soil near the surface generally varies with the season, but remains within a narrower range from about 2.5 to $6 \mathrm{~m}$, where it varies from about 18 to $24 \mathrm{vol} \%$. This level of moisture at all elevations is sufficient to support growth of paraffin degrading microorganisms.

The rate of biodegradation of a paraffin monolith was calculated using rates of $8.18 \mathrm{E}-02 \mathrm{~kg} / \mathrm{m}^{2} / \mathrm{yr}$ and $2.85 \mathrm{E}-01 \mathrm{~kg} / \mathrm{m}^{2} / \mathrm{yr}$ from data presented in the America Petroleum Institute's Robust Summary. ${ }^{17}$ This calculation, provides an order of magnitude bounding estimate on the rate of biodegradation of paraffin. The biodegradation rates used come from well mixed, aqueous, shake flask experiments using mineral media at $20^{\circ} \mathrm{C}$ and a microbial inoculum from a land farming facility for oil contaminated soil. The size of the monoliths used in the estimate are based on the projected minimum monolith size for grouting the beryllium blocks in the SDA. ${ }^{24}$ The following assumptions were used in the estimation of the rate of paraffin biodegradation in the SDA: 1. surface area of the monolith remains constant with 
time, 2. monolith is $100 \%$ paraffin, 3 . biodegradation rate of paraffin is not limited by the availability of oxygen or other nutrients, 4. other compounds present in WAXFIX do not affect the rate of biodegradation of paraffin, 5. metabolism products from biodegradation do not affect the rate of biodegradation, 6 . no other conditions or process in the subsurface affect the rate of biodegradation.

Calculated results using the data from the land farming facility were chosen because they were believed to be more representative of the conditions at the SDA. These results estimate an area based biodegradation rate that ranges from 0.0818 to $0.285 \mathrm{~kg} / \mathrm{m}^{2} /$ year. Two monoliths sizes were considered based on the location of the beryllium block: 1 . a cylindrical monolith $2.5 \mathrm{~m}$ in diameter X $5 \mathrm{~m}$ in height with an initial surface area of $49.09 \mathrm{~m}^{2}$, an initial mass of $21599 \mathrm{~kg}$ and a thickness of $0.46 \mathrm{~m}(18$ inches) beyond the beryllium block, and 2. a block monolith $2 \mathrm{~m} \mathrm{X} 3 \mathrm{~m} \mathrm{X} 5 \mathrm{~m}$ with an initial surface area of $62 \mathrm{~m}^{2}$, an initial mass of $26400 \mathrm{~kg}$, and a thickness of $0.46 \mathrm{~m}$ (18 inches) beyond the beryllium block.

For the cylindrical monolith, the calculated rate of mass loss is 4 to $14 \mathrm{~kg}$ per year. At this rate it will take 1500 to 5400 years for microorganisms to consume the monolith. For the block monolith, the calculated rate of mass loss is 5 to $18 \mathrm{~kg}$ per year; microorganisms will take 1500 to 5200 years to consume the monolith. The outer $0.46 \mathrm{~m}$ (18 inches) layer of each monolith, which represents the minimum expected distance to the beryllium block, was calculated to require 1000 to 3600 years to be consumed.

The $\mathrm{pH}$ of the soils at the SDA is slightly alkaline, generally a $\mathrm{pH}$ of about $8,{ }^{25}$ and is within the range of conditions for growth of paraffin-degrading microorganisms. The temperature of the soil varies with the season and with depth. The temperature of the soil surrounding the waste will generally range from 7 to $15^{\circ} \mathrm{C}$, which is below the optimum temperature for paraffin degradation, but within the range of viability for use of paraffin by the microorganisms. This suggests the degradation rate of paraffin in the SDA would be slower than that observed in the calculations and articles referenced above. The soil 
gases measured at the SDA generally indicate aerobic conditions ${ }^{26}$ and would support paraffin degradation; however, the rate of degradation might be limited by the rate of oxygen diffusion to the surface of the paraffin. The soils at the SDA are generally low in nitrogen $(0.01 \mathrm{wt} \%)$ and phosphate ( 0.01 to $0.16 \mathrm{wt} \%),{ }^{25,27}$ two elements required for growth of paraffin degrading microorganisms. In the waste, the paraffin would form a monolith and would have a low surface to volume ratio. During the grouting process, some soil would be intimately mixed with the paraffin, but this would effectively isolate the soil from other compounds required for degradation. Overall, degradation of paraffin by microorganisms in the SDA is possible and even likely, but the rate of degradation will be slower than the referenced studies, which were under well-mixed, high surface area-to-volume ratio, and welloxygenated conditions. ${ }^{15-19,21,22,28}$

\section{CONCLUSION}

Radiation damage to the crystalline structure of paraffin is not as substantial as damage to other hydrocarbon-based materials, such as plastics. Although a dose level for damage to paraffin was not found in the literature, damaging doses in plastics can be initiated but are minor at $10^{5}$ Gy and become more severe at $10^{7} \mathrm{~Gy}$. Conservative doses in the SDA were calculated for the highest activity ATR beryllium block that may be grouted. The calculations indicate that Co-60 dominates the source term in the next decade and its domination is probable for decades into the future. Based on these calculations, WAXFIX probably would not reach a level of radiation damage for many hundreds of years.

There are a broad range of microorganisms that can metabolize paraffin. Conditions for metabolization cover a wide range of temperatures, chemical conditions, and moisture levels; these conditions overlap SDA conditions, indicating degradation of a paraffin-based grout by microorganisms 
in the SDA is possible and even likely. The rate of biodegradation for two paraffin monoliths, sized for application to beryllium blocks, was estimated using literature data for conditions much more favorable to biodegradation than those present at the SDA. The calculations showed that 1000 to 3600 years would be required to biodegrade the outer $0.46 \mathrm{~m}$ (18 inches) layer of each monolith, which represents the minimum expected distance to the beryllium block.

\section{REFERENCES}

1. Hanson, D. J., G. E. Matthern, N. A. Yancey, and D. L. Knudson, 2004, Evaluation of the Durability of WAXFIX for Subsurface Applications, ICP/EXT-04-00300, Rev. 0, Idaho Completion Project.

2. United States Patent Office \# 6,569,235, Grout compositions for construction of subterranean barriers

3. Milian, L. W., J. H. Heiser, J. W. Adams, and S. P. Rutenkroeger, 1997, In-Situ Stabilization of TRU/Mixed Waste Project at the INEEL, BNL-64958, Brookhaven National Laboratory, Upton, New York.

4. Heiser, J. H. and M. Fuhrmann, 1997, "Materials Testing for In Situ Stabilization Treatability Study of INEEL Mixed Waste Soils," September 1997 Attachment A to "Final Report - In Situ Stabilization Treatability Study at the Radioactive Waste Management Complex," HMP-49, Rev. 01, MSE Technology Applications, Inc.

5. Mullen, Carlen K., Glen R. Longhurst, Michael L. Carboneau, and James W. Sterbentz, 2003, Beryllium Waste Transuranic Inventory in the Subusrface Disposal Area, Operable Unit 7-13/14, INEEL/EXT-01-01678, Rev. 2, Idaho National Engineering and Environmental Laboratory, March 2003. 
6. Croff, A. G., 1980, ORIGEN2-A Revised and Updated Version of the Oak Ridge Generation and Depletion Code, ORNL-5G21, Oak Ridge National Laboratory, Oak Ridge, Tennessee.

7. MicroShield, Version 6, Rockville, Maryland: Grove Engineering, 2003.

8. Ungar, G., 1980, "Effect of radiation on the crystals of polyethylene and paraffins: 2 Phase separation in gamma-irradiated paraffins," Biennial Conference on Polymer Physics, Weybridge, United Kingdom, September 10-12, 1979, Polymer, Vol. 21, November 1980.

9. Ungar, G., D. T. Grubb, and A. Keller, 1980, "Effect of radiation on the crystals of polyethylene and paraffins: 3 Irradiation in the electron microscope," Polymer, Vol. 21, November 1980.

10. Mahmood, F. Mayahi and M. M. Mousa, 1972, "Effect of Gamma Radiation on Pure Paraffin Wax and on Wax-Acetone System,” J. Indian Chem. Soc., Vol. 49, No. 10.

11. CRC Handbook of Tables for Applied Engineering Science, 1983, $2^{\text {nd }}$ Edition, Ray E. Bolz and George L. Tuve (eds.).

12. Ponsford, A.P., 1966, "Microbiological Activity in Relation to Coal Utilisation: Par II Coal and Hydrocarbons," The British Coal Utilisation Research Association, Monthly Bulletin, Vol. XXX, No. 2, February-March, 1966, Part I.

13. Leahy, J. G. and R. R. Colwell, 1990, "Microbial Degradation of Hydrocarbons in the Environment," Microbiological Reviews, Vol. 54, No. 3, pp. 305-315, September 1990.

14. Bishop, M. D. and D. R. Woodward, 1990, "Biological Paraffin Control Systems Show Production Increases in Addition to Controlling Paraffin," Petroleum Society of CIM/Society of Petroleum Engineers, Calgary, June 10-13, 1990, Paper No. CIM/SPE 90-56, pp. 56-1 to 56-9. 
15. Kuyukina, M. S., I. B. Ivshina, M. I. Ritchkova, J. C. Philp, C. J. Cunningham, and N. Christofi, 2003, "Bioremediation of Crude Oil-Contaminated Soil Using Slurry-Phase Biological Treatment and Land Farming Techniques," Soil and Sediment Contamination, Vol. 12, No. 1, pp. 85-99.

16. Blenkinsopp, S. A., W. Jansen, J. Boivin, and J. W. Costerton, 1992, "Paraffin Removal DownHole," Institute of Gas Technology (IGT) International Symposium on Gas, Oil, Coal, and Environmental Biotechnology, Colorado Springs, Colorado, December 9-11, 1991, CONF-911251, pp. 419-425, 1992, Chicago, Illinois Institute of Gas Technology.

17. American Petroleum Institute, 2004, "Robust Summary of Information on Waxes and Related Materials," Abstracts of Petroleum Refining and Petrochemical Literature, March 27, 2003, pp. 156.

18. Davie, I. N., J. P. Winter, and R. P. Varoney, 1995, "Decomposition of Coated Papers from a Quick-service Restaurant,” Tappi Journal, Vol. 78, No. 5, pp. 127-130, May 1995.

19. Soriano, A. U. and N. Pereira Jr., 2002, “Oily Sludge Biotreatment," 9th Annual International Petroleum Environmental Conference, Albuquerque, New Mexico, October 22-25, 2002.

20. Rosenberg, E., 1991, The Prokaryotes: A Handbook on the Biology of Bacteria: Ecophysiology, Isolation, Identification, Applications, "Chapter 19, The Hydrocarbon-Oxidizing Bacteria," New York: Springer-Verlag, $2^{\text {nd }}$ Edition, Vol. 1, pp. 446-459, A. Balows, H. G. Truper, M. Dworkin, W. Harder, and K. Schleifer (eds.).

21. Ferguson, K. R., C. T. Lloyd, D. Spencer, and J. Hoeltgen, 1996, "Microbial Pilot Test for the Control of Paraffin and Asphaltenes at Prudhoe Bay," Society of Petroleum Engineers Annual Technical Conference and Exhibition, Denver, Colorado, October 6-9, 1996. 
22. Brown, L. R., 1987, “Oil-Degrading Microorganisms: Using microorganisms to treat oil spills is in the experimental stage, but further research may prove its utility in removing oil from the environment," Chemical Engineering Progress, October 1987, pp. 35-40.

23. United States Geological Survey, "Hydrological and Meteorological Data for an Unsaturated Zone Study near the Radioactive Waste Managemetn Complex, Idaho National Engineering Laboratory, Idah - 1985-86,” U.S. Geological Survey Open-File Report 89-74, DOE/ID-22079, April, 1989.

24. EDF-4397, 2004, "Grout Selection Criteria and Recommendation for the OU 7-13/14 In Situ Grouting Early Action Project,” Rev. 0, Idaho National Engineering and Environmental Laboratory, February 2004.

25. Mincher, Bruce J., Robert V. Fox, Catherine L. Riddle, D. Craig Cooper, and Gary S. Groenewold, 2004, "Strontium and Cesium Sorption to Snake River Plain, Idaho Soil," Radiochim. Acta, Vol. 92, pp. 55-61.

26. Rightmire, C. T. and B. D. Lewis, 1987, Hydrogeology and Geochemistry of the Unsaturated Zone, Radioactive Waste Management Complex, Idaho National Engineering Laboratory, Idaho, U.S. Geological Survey Water-Resources Investigations Report 87-4198, (DOE/ID-22073), U.S. Geological Survey.

27. Dechert, Thomas V., Paul A. McDaniel, and Anita L. Falen, 1994, Aggradational and Erosional History of the Radioactive Waste Management Complex at the Idaho National Engineering Laboratory, EGG-WM-11049, Idaho National Engineering and Environmental Laboratory.

28. Marino, Fabien, 1998, Biodegradation of Paraffin Wax, Thesis: Department of Chemical Engineering, McGill University, Montreal, Canada. 


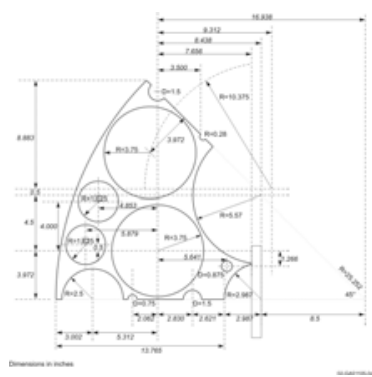

Figure 1. Cross-section diagram of an Advanced Test Reactor beryllium block.

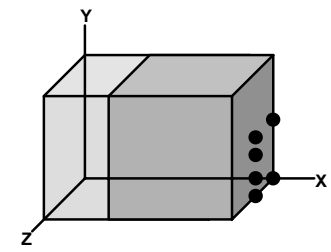

Figure 2. MicroShield rectangular model of an ATR beryllium block with wax showing calculated fluence positions.

\begin{tabular}{|c|c|c|c|c|}
\hline All Positions & $\begin{array}{c}2004 \text { No Wax } \\
\mathrm{MeV} / \mathrm{cm}^{2}-\mathrm{s} \\
(\mathrm{Gy} / \mathrm{hr})\end{array}$ & $\begin{array}{c}2004 \text { With Wax } \\
\mathrm{MeV} / \mathrm{cm}^{2}-\mathrm{s} \\
(\mathrm{Gy} / \mathrm{hr})\end{array}$ & $\begin{array}{c}2014 \text { No Wax } \\
\mathrm{MeV} / \mathrm{cm}^{2}-\mathrm{s} \\
(\mathrm{Gy} / \mathrm{hr})\end{array}$ & $\begin{array}{c}2014 \text { With Wax } \\
\mathrm{MeV} / \mathrm{cm}^{2}-\mathrm{s} \\
(\mathrm{Gy} / \mathrm{hr})\end{array}$ \\
\hline Minimum & $0.81 \times 10^{8}(1.41)$ & $\begin{array}{l}0.17 \times 10^{7} \\
(0.030)\end{array}$ & $\begin{array}{l}0.22 \times 10^{8} \\
(39)\end{array}$ & $\begin{array}{l}0.05 \times 10^{7} \\
(0.008)\end{array}$ \\
\hline Maximum & $\begin{array}{l}2.29 \times 10^{8} \\
(4.00)\end{array}$ & $\begin{array}{l}0.35 \times 10^{7} \\
(0.061)\end{array}$ & $\begin{array}{l}0.64 \times 10^{8} \\
(112)\end{array}$ & $\begin{array}{l}0.10 \times 10^{7} \\
(0.017)\end{array}$ \\
\hline Mean & $\begin{array}{l}1.69 \times 10^{8} \\
(2.96)\end{array}$ & $\begin{array}{l}0.27 \times 10^{7} \\
(0.048)\end{array}$ & $\begin{array}{l}0.47 \times 10^{8} \\
(83)\end{array}$ & $\begin{array}{l}0.08 \times 10^{7} \\
(0.013)\end{array}$ \\
\hline
\end{tabular}

Table I. Summary of MicroShield calculated fluence and exposure rates for the six positions on the beryllium block with and without wax. 


\footnotetext{
${ }^{\mathrm{i}}$ Product Disclaimer - References herein to any specific commercial product, process, or service by trade name, trademark, manufacturer, or otherwise, does not necessarily constitute or imply its endorsement, recommendation, or favoring by the U.S. Government, any agency thereof, or any company affiliated with the Idaho National Laboratory.
} 